\title{
EDITORIAL
}

\section{The Commission Proposal to Replace Unanimity with a Qualified Majority in the Case of Tax Matters}

\section{INTRODUCTION}

In its Communication to the European Parliament, the European Council and the Council, 'Towards a more Efficient and Democratic Decision Making in EU Tax Policy' (the Communication), ${ }^{1}$ the Commission proposes to replace the unanimity vote on harmonization of taxes by a qualified majority. A shift to ordinary legislative procedure would benefit from European Parliament input, and therefore increase democratic accountability. ${ }^{2}$

Under the ordinary legislative procedure, the Commission would submit a proposal to the European Parliament and the Council, where joint approval is required. There are several possible steps until the act is approved or rejected, consisting of three readings. In general, the Parliament will approve an act by majority and the Council by a qualified majority. ${ }^{3}$

As from 1 November 2014, a qualified majority requires approval of at least $55 \%$ of the members of the Council, comprising at least fifteen of them ${ }^{4}$ and representing Member States comprising at least $65 \%$ of the population of the Union. ${ }^{5}$ The Treaty of the European Union (TEU) also foresees the possibility of a blocking minority, which must include at least four Council Members, failing which the qualified majority will be deemed to be attained. ${ }^{6}$

There are two major sets of arguments asserted in the Communication, in favour of a shift from the unanimity requirement for tax harmonization, to the qualified majority. The latter will assure a 'better tax policy for a stronger and more competitive single market', and the need for a 'pooled sovereignty to protect national tax sovereignties'.
A stronger and more competitive single market plays in favour of strengthening the European Union and its law. A pooled sovereignty to protect national tax sovereignties is only apparently contradictory. It is a call for coordination, as a condition of survival of national tax sovereignties in the context of free movement and multilateralism.

Both arguments are complementary, and aimed at justifying legitimacy of the qualified majority procedure in light of the Treaty of Lisbon and the national constitutions of the Member States. They are further developed in the Proposal. In the present editorial, some critical considerations are put forward.

\section{A 'STRONGER AND MORE COMPETITIVE SINGLE MARKET'}

The need for a 'stronger and more competitive single market' aims to justify a stronger, quicker, and more efficient shift of competences to the EU in tax matters. The Commission correctly states that a purely national approach to taxation no longer works, because national and EU common interests are intertwined. It is also correct that coordinated EU action in taxation is a condition for protecting the revenues of Member States, ${ }^{7}$ although redistribution of revenues and competitiveness of Member States is not assured by the shift to a qualified majority of voting as such.

The main problem with the introduction of a qualified majority in the harmonization of taxes is related to the unlimited scope of tax harmonization, while, at the same time, taxes remain to be national resources, and the EU

\section{Notes}

Eur. Commission, Communication to the European Parliament, the European Council and the Council, Towards a more Efficient and Democratic Decision Making in EU Tax Policy, $\operatorname{COM}(2019) 8$ final (Strasbourg: 15 Jan. 2019).

Eur. Commission, supra n. 1, at 11 .

Art. 294 Treaty on the Functioning of the European Union (TFEU).

This requirement is superfluous with at least twenty-six Member States. See P. González Saquero, La Mayoría Cualificada en el Consejo da le UE según el Tratado de Lisboa, 31 Revista Española de Derecho Europeo 309, 316-17 (2009).

Art. 16(4) Treaty of the European Union (TEU).

Art. 16(4) TEU. On the qualified majority procedure, see González Saquero, supra n. 4, at 316 et seq

Eur. Commission, supra n. 1, at 1. 
budget is insufficient to compensate Member States for the loss of revenue or competitiveness.

On the scope of tax harmonization, the Commission recalls Article 2 of the 'Protocol on the Concerns of Irish People on the Treaty of Lisbon', stating that '[n]othing in the Treaty of Lisbon makes any change of any kind, for any Member State, to the extent or operation of the competence of the European Union'. ${ }^{8}$ Moving to qualified majority voting would not affect the current tax competences of Member States, and would have no implications for the scope of harmonization, as it would correspond to the scope provided in Articles 113 and 115 of the Treaty on the Functioning of the European Union (TFEU). In the case of indirect taxes, it would take place to the extent that such harmonization is necessary to ensure the establishment and the functioning of the internal market and to avoid distortion of competition (Article 113); in the case of direct taxes, directives for the approximation of such laws, regulations or administrative provisions of the Member States would take place when the latter directly affect the establishment or functioning of the internal market (Article 115).

In truth, in spite of the afore-mentioned written Protocol and written scope, the EU competence on tax harmonization has no limits, as the internal market integration has meant a dynamic expansion of EU competences, and ultimately in a globalized world, (almost) all taxes will affect the establishment or functioning of the internal market, and may distort competition.

The history of the proposals by the Commission for Directives on harmonization of taxes (see the paradigmatic example of the Savings Directive), ${ }^{9}$ the regulatory role that some taxes are claimed to play in the EU's wider policy priorities, ${ }^{10}$ as well as the case law of the EU Court of Justice, ${ }^{11}$ illustrate the afore-mentioned state of affairs.

Moreover, harmonization in the tax field comprises harmonization of existing national taxes, or the creation of new national but harmonized taxes. Both may be justified under Article 26(1) and Article 115(1) of the TFEU.

\section{UnANIMITY AS AN OBSTACLE TO PROGRESS}

According to the Commission, unanimity has allegedly 'hampered progress on important tax initiatives needed to strengthen the Single Market and boost EU competitiveness'. Inaction with regard to the definitive VAT regime, the common consolidated corporate tax base (CССТВ), the financial transactions tax and the digital services tax has cost EUR 292 billion a year.

It is not clear in the Communication as to how the Commission reached the asserted figures, and whether the Commission took into account potential negative effects on the investment location, in the event that those regimes were introduced. Moreover, the examples chosen for the debate will raise more controversy than persuasion, as it is hardly possible to compare the relevance for the single market and its competitiveness, of a definitive VAT regime, with the relevance and adequacy of a financial transactions tax, or the adequacy of the digital services $\operatorname{tax}^{12}$

\section{Pooled sovereignty: QuAlified MAJORITY AND THE RULE OF LAW IN TAXES}

Granting legitimacy to tax harmonization based on a qualified majority of votes is controversial in the European Union, due to requirements under Member States' national constitutions. Taxation is reserved to national parliaments and legislation. Before the entry into force of the afore-mentioned qualified majority rules and the co-decision by the European Parliament and the Council, the so-called 'democratic deficit' of the European Union allegedly justified the unanimity rule in taxes.

The fact that most EU legal fields are now approved by majority, including criminal matters (also reserved to national parliaments and legislation) is not per se a justification to shift the unanimity requirement in tax harmonization.

The qualified majority rules under the TEU, together with the (ordinary) legislative process under the TFEU, increased EU democratic representation. However, whether representation of national voters - and with it the rule of law, democratic legitimacy and separation of powers - are assured by the qualified majority process should be critically discussed before moving forward.

Currently, unanimity guarantees that each national parliament is indirectly represented by its government, because it emerges from the parliamentary majority. Unanimity guarantees that in the event that there is no national parliamentary support to approve a Directive, a Member State is expected to veto it.

\section{Notes}

8 Protocol on the Concerns of the Irish People on the Treaty of Lisbon, OJ L60/131, 2 Mar. 2013.

9 EU Savings Directive: Council Directive 2011/16/EU of 15 Feb. 2011 on administrative cooperation in the field of taxation and repealing Directive 77/799/EEC, OJ L64/1 (11 Mar. 2011). See A. P. Dourado, The EC Draft Directive on Interest from Savings from a Perspective of International Tax Law, 9(3) EC Tax Rev. 144 (2000).

10 Eur. Commission, supra n. 1 , at 5 .

11 Involving over ten topics, only in direct taxes: as addressed, e.g. in European Tax Law, vol. 1, General Topics and Direct Taxation (B. Terra \& P. J. Wattel eds, 7 th ed., Wolters Kluwer 2018).

12 See these examples cited in Eur. Commission, supra n. 1, at 4. 
With a qualified majority approach, all Member States will have to accept the regime approved by the qualified majority. Each Member State that has not approved a Directive will have to transpose it and implement it, against its national democratic representation, due to the primacy principle. Moreover, the Directive is granted direct effect. This means that resorting to a qualified majority with regard to tax matters may create frictions between national sovereign powers on the one hand, and EU institutions and the principle of primacy on the other.

\section{LegisLative inItIATIVE}

Legislative initiative also needs to be subjected to critical review. The composition and procedure of the Commission and its competence to choose which taxes should be harmonized or introduced, in order to strengthen the single market and boost competitiveness (the financial transactions tax? a digital services tax?) are not incompatible with the rule of law and separation of powers, analysed in light of national constitutional systems. In fact, legislative initiatives in national law are often raised by governments and not by parliaments. ${ }^{13}$

However, national governments emerge from parliamentary majorities, and there is only the national interest at stake. Determining the EU interest - a supranational interest - is the task of the Commission. However, in the current EU composed of twenty-eight Member States, the EU interest has become difficult to determine and the Commission is unable to anticipate the consequences of tax harmonization in each and every Member States.

Tax harmonization initiatives, and the reason why a specific object of tax harmonization is chosen, if normally based on rational, understandable reasons (e.g. the AntiTax Avoidance Directive), would at least need to correspond to a more transparent process. This has been done in the preamble of Directives, but the negotiation procedure is not sufficiently clear in terms of consequences for the economy of each Member State, normally leaving that assessment to each State.

\section{QuALIFIED MAJORITY IN TAXES AND WIDER POLICY PRIORITIES}

Still, according to the Commission, unanimity has a detrimental effect on other ('wider') policy priorities, including the European and Monetary Union (EMU), the Capital Markets Union, the Digital Single Market, the 2030 Climate and Energy Framework and the circular economy. The example of the proposal for an energy tax directive put forward in the Communication, illustrates that proposals on taxes with regulatory purposes may increase in coming years, similarly to what has happened in the Member States.

Regulatory taxation would certainly benefit from a qualified majority procedure, and the underlying discussion should concern whether the example of national legislation vastly spreading regulatory taxation would be desirable at the EU level. It is not certain whether the discussion at the level of the Council and the EU Parliament would guarantee that the Member States tax systems are not more jeopardized than now.

In any case, a shift to a qualified majority to accelerate efficiency is, in principle, compatible with the aims of the $\mathrm{EU}$, and the competences allocated to it.

\section{The autonomy of eU LaW}

It could be argued that action 'Towards a more Efficient and Democratic Decision Making in EU Tax Policy', ${ }^{14}$ and the democratic legitimacy of EU law voted by a qualified majority, is justified by the autonomy of EU law in respect of national legislation. Whereas almost sixty years ago, the European Court of Justice put forward the direct effect principle of European Community law, from which derived the primacy principle (the Van Gend $\varepsilon$ Loos case), ${ }^{15}$ the ECJ now refers to the autonomy of EU law with respect to both the law of the Member States and international law.

The EU constitutional structure allowed its law to develop as a set of common values on which the EU is founded, as stated in Article 2 of the TEU. In turn, the set of common values on which the EU is set up, fostered the principle of mutual trust and sincere cooperation.

EU law was characterized by the Court in Opinion 2/13 (Accession of the EU to the ECHR) ${ }^{16}$ and the recent Achmea case, ${ }^{17}$ according to several features. The Court has acknowledged the constitutional structure of the EU and its law; the primacy principle; the direct effect of EU provisions; mutually interdependent legal relations binding the EU and its Member States reciprocally and binding its Member States to each other; and the fundamental premise that each Member State shares with all the other

\section{Notes}

13 For many examples, see A. P. Dourado, General Report, In Search of Validity in Tax Law: The Boundaries Between Creation and Application in a Rule-of-Law State, in Separation of Powers in Tax Law (A. P. Dourado ed., IBFD 2010), at 32-33 (book based on the proceedings of the 2009 annual meeting of the EALTP).

14 Eur. Commission, supra n. 1.

15 ECJ, 5 Feb. 1963, NV Algemene Transport- en Expeditie Onderneming van Gend \& Loos v. Netherlands Inland Revenue Administration, ECLI:EU:C:1963:1.

16 ECJ, 18 Dec. 2014, Accession of the European Union to the European Convention for the Protection of Human Rights and Fundamental Freedoms (Adhésion de l'Union à la CEDH), ECLI:EU:C:2014:2454, paras 165-73 and the case law cited.

17 SK: ECJ, 6 Mar. 2018, Slowakische Republik v. Achmea BV, ECLI:EU:C:2018:158, paras 33 \& 34. 
Member States. Furthermore, the Court recognizes that they share with it a set of common values on which the EU is founded, as stated in Article 2 of the TEU, namely mutual trust and sincere cooperation. From these concepts also emerges an effective and uniform application of EU law by authorities of the Member States, as well as State liability. ${ }^{18}$

The autonomy of EU law and its characterization are critical to assure its effectiveness and the rule of law in the European Union, and it also has significant legitimizing functions. ${ }^{19}$ However, it is not sufficient to avoid frictions with national parliaments and voters. More than that, if the friction were to be translated into national parliaments that are not friendly towards EU integration, or if the institutions of a Member State do not respect the rule of law, autonomy of EU law will be suspended.

\section{Conclusion}

In order to achieve a swift move towards approval by a qualified majority, the Commission crafted a roadmap for a progressive and targeted transition. It also pledges the use of passerelle clauses (Article 48(7) of the TEU, for example), with no need to revise the Treaties. However, caution is recommended. In order to avoid the various frictions mentioned above, several alternatives should be carefully weighted.

Comparison with other EU competences exercised by qualified majority, would recommend that EU tax competences be exercised by regulations which apply directly with no need (or possibility) to be transposed, and therefore no opportunity for national parliaments to create obstacles. Nevertheless, this would not avoid negative reactions by national voters. Alternatively, approval by a qualified majority should be limited to the first three steps of the roadmap for the transition. The first two steps are as follows:
- 'measures that have no direct impact on the taxing rights, bases or rates of Member States, but are critical for combating tax fraud, evasion and avoidance and in facilitating tax compliance for businesses in the Single Market'. ${ }^{20}$ These measures do not interfere with national revenue and, on the contrary, are critical in assisting Member States to collect that revenue; and

- 'measures primarily of a fiscal nature designed to support other policy goals. This may include in particular the fight against climate change, protecting the environment or improving public health or transport policy'. ${ }^{21}$ These measures, if related to EU policies, could be submitted to the qualified majority procedure and, more significantly, be part of the EU budget.

In general, a proposal to shift tax harmonization to approval by a qualified majority would be interesting if new taxes, including those with a regulatory nature, were to become EU resources targeted at implementing EU policies.

The third step would be to focus on areas of taxation that are already largely harmonized and which must evolve and adapt to new circumstances. This would, in particular, cover VAT and excise duties. ${ }^{22}$ Qualified majority voting in these areas, including direct taxes, would be easier to achieve if there were opt-in and optout clauses, as well as sunset clauses in respect of more controversial measures. The latter would force Member States to decide whether a certain regime had proven well or ought to be changed.

If unanimity is retained in the cases mentioned in the fourth step ('other initiatives in the taxation area, which are necessary for the Single Market and for fair and competitive taxation in Europe'), such as the CССТВ ${ }^{23}$ opt-in and optout clauses, as well as sunset clauses are also advisable ${ }^{24}$ in order to facilitate the required consensus.

Ana Paula Dourado General-Editor

\section{Notes}

18 A. von Bodgdandy \& M. Ioannidis, Systemic Deficiency in the Rule of Law: What It Is, What Has Been Done, What Can Be Done, 51(1) Common Mkt. L. Rev. 59, 64-65 (2014).

19 Ibid.

20 Eur. Commission, supra n. 1, at 11

21 Ibid.

22 Ibid.

23 Ibid., at 12

24 Proposing opt-out and sunset clauses: W. Schön, Facilitating Entry by Facilitating Exit: New Paths in EU Tax Legislation, 46(4) Intertax 339-41 (2018). 